DOI https://doi.org/10.30525/978-9934-26-008-7.2-1

\title{
PROSPECTS OF USING ALCOHOL IN CITRUS INFUSIONS IN THE TECHNOLOGY OF THE RESTAURANT
}

\author{
Kuzmin O. V., Rizhenko V. V.
}

\section{INTRODUCTION}

Today, the range of sweet dishes in restaurants is expanding every day in number and range. There is a large number of new varieties of sweet dishes for health and functional purposes ${ }^{1}$, so the modern consumer attaches special importance to the consequences associated with their use. After all, it is known that sweet foods contain a large amount of fats and carbohydrates, are quite high in calories and a small amount satisfies the body with the necessary substances in the daily diet $^{2}$. Therefore, the creation of sweet dishes, which to a lesser extent have a detrimental effect on the body, is constantly supported to satisfy the desires of consumers.

A wide range of sweet dishes is based on the use of various raw materials, which are substitutes for existing, but with more useful properties $^{3}$. On the one hand, this gives the product functional properties,

\footnotetext{
${ }^{1}$ Andreou V., Strati I.F., Fotakis C., Liouni M., Sinanoglou V.J. Herbal distillates: A new era of grape marc distillates with enriched antioxidant profile. Food Chemistry. 2018. 253, pp. 171-178. DOI 10.1016/j.foodchem.2018.01.162; Dietrich I., Kuzmin O., Mikhailenko V. Comprehensive evaluation of the hot sweet soufflé dessert quality. Ukrainian Journal of Food Science. 2017. 5 (1). pp. 92-102. DOI 10.24263/2310-10082017-5-1-12; Kuzmin O., Kovalchuk Y., Velychko V., Romanchenko N. Improvement technologies of aqueous-alcoholic infusions for the production of syrups. Ukrainian Journal of Food Science. 2016. 4 (2). pp. 258-275. DOI 10.24263/2310-1008-2016-4-2-8; Chandrasekara A., Shahidi F. Herbal beverages: Bioactive compounds and their role in disease risk reduction - A review. Journal of Traditional and Complementary Medicine. 2018. 8 (4). pp. 451-458. DOI 10.1016/j.jtcme.2017.08.006.

2 Kuzmin O., Kovalchuk Y., Velychko V., Romanchenko N. Improvement technologies of aqueous-alcoholic infusions for the production of syrups. Ukrainian Journal of Food Science. 2016. 4 (2). pp. 258-275. DOI 10.24263/2310-1008-2016-4-2-8.

${ }^{3}$ Dietrich I., Kuzmin O., Mikhailenko V. Comprehensive evaluation of the hot sweet soufflé dessert quality. Ukrainian Journal of Food Science. 2017.5 (1). pp. 92102. DOI 10.24263/2310-1008-2017-5-1-12; Chandrasekara A., Shahidi F. Herbal beverages: Bioactive compounds and their role in disease risk reduction - A review. Journal of Traditional and Complementary Medicine. 2018. 8 (4). pp. 451-458. DOI 10.1016/j.jtcme.2017.08.006.
} 
on the other - to varying degrees change the taste of the usual consumer recipe of the product ${ }^{4}$. Thus, the question of finding the key moments of the influence of sweet dishes on the body and their solution with minimal impact on its organoleptic characteristics becomes relevant.

The most promising for research is a group of sweet dishes - creams, they are prepared from thick (containing at least 35\% fat) cream or sour cream $36 \%$ fat with the addition of eggs, butter, milk, sugar, fruit puree and gelatin, as well as various flavoring and aromatic products.

The main tool that ensures the viability of any organism and regulates the ratio of energy to maintain homeostasis (relative dynamic constancy of the composition and properties of the internal environment and the stability of basic physiological functions of the body) and is spent on regeneration of body cells $\mathrm{s}^{5}$. This rate depends on the concentrations and ratios of oxidative and reducing forms of substances ${ }^{6}$ in the body, including substances that come with food and drink. Therefore, one of the most important factors in regulating the parameters of redox reactions ${ }^{7}$ is the redox potential ${ }^{8}$.

${ }^{4}$ Kuzmin O., Levkun K., Riznyk A. Qualimetric assessment of diets. Ukrainian Food Journal. 2017. 6, 1. pp. 46-60. DOI: 10.24263/2304-974X-2017-6-1-7.

5 Бахир В.М. Электрохимическая активация. М.: ВНИИИМТ. 1992. 2 ч. 657 с.; Прилуцкий В.И., Бахир В.М. Электрохимически активированная вода: аномальные свойства, механизм биологического действия. Москва : ВНИИИМТ. 1997. 228 с.; Леонов Б.И., Прилуцкий В.И., Бахир В.М. Физикохимические аспекты биологического действия электрохимически активированной воды : монография. Москва : ВНИИИМТ. 1999. 244 с.; Бахир В.М. Медико-технические системы и технологии для синтеза электрохимически активированных растворов. М. ВНИИИМТ. 1998. 66 с.

6 Прилуцкий В.И., Бахир В.М. Электрохимически активированная вода: аномальные свойства, механизм биологического действия. Москва : ВНИИИМТ. 1997. 228 с.; Леонов Б.И., Прилуцкий В.И., Бахир В.М. Физико-химические аспекты биологического действия электрохимически активированной воды : монография. Москва : ВНИИИМТ. 1999. 244 с.; Бахир В.М. Медико-технические системы и технологии для синтеза электрохимически активированных растворов. М. ВНИИИМТ. 1998. 66 с.; Бахир В.М. Современные технические электрохимические системы для обеззараживания, очистки и активирования воды. Москва : ВНИИИМТ, 1999. 84 с.

${ }^{7}$ Kawa-Rygielska J., Adamenko K., Kucharska A.Z., Szatkowska K. Fruit and herbal meads - Chemical composition and antioxidant properties. Food Chemistry. 2019. 283. pp. 19-27. DOI 10.1016/j.foodchem.2019.01.040; Kuzmin O., Suikov S., Niemirich O., Ditrich I., Sylka I. Effects of the water desalting by reverse osmosis on the process of formation of water-alcohol mixtures. ${ }^{l} H$ NMR spectroscopy studies. Ukrainian Food Journal. 2017. 6 (2). pp. 239-257. DOI: 10.24263/2304-974X-2017- 
In the technology of creams, one of the ways to influence its antioxidant properties is the extraction of plant components into alcoholcontaining raw materials. Therefore, creams should not only perform their main technological function - to moisturize and improve the organoleptic characteristics of confectionery, but also should enrich the finished product with useful substances for the human body and provide the desired properties. This is possible due to the introduction into the formulation of creams of infusions of alcohol from vegetable raw materials (both aromatic and non-aromatic). Due to the extraction of plant raw materials into alcohol-containing raw materials, the latter is enriched with nutrients (vitamins, minerals, organic acids, polyphenolic compounds), which leads to increased antioxidant properties.

In addition, plant raw materials are a seasonal product, and the aqueous-alcoholic environment retains all the nutrients extracted from plants and have high rates of reduction energy, and due to the high antioxidant properties, there is an increase in their shelf life.

Therefore, the aim of the work is to scientifically substantiate and improve the formulation of creams and provide them with functional and health properties.

To achieve this goal it is necessary to solve the following tasks:

- theoretically substantiate the prospects of using alcohol infusions from vegetable raw materials in the production of creams;

- study of antioxidant activity of alcohol infusions from vegetable raw materials;

- identification of the most promising sources of natural antioxidants for use in the technology of creams;

- determination of rational proportions of creams;

6-2-6; Kuzmin O., Suikov S., Koretska I., Matiyashchuk O., Poliovyk V. Identification of equilibrium state of hydroxyl protons in vodkas by ${ }^{l} H$ NMR spectroscopy. Ukrainian Food Journal. 2017. 6 (2). pp. 314-336. DOI: 10.24263/2304-974X-2017-6-1-12; Kuzmin O., Topol'nik V. Eduction of transitional equilibrium in vodkas by means of ${ }^{1} H$ NMR spectroscopy. The advanced science journal. 2014. 12. pp. 61-64. DOI: 10.15550/ASJ.2014.12.061.

${ }^{8}$ Chandrasekara A., Shahidi F. Herbal beverages: Bioactive compounds and their role in disease risk reduction - A review. Journal of Traditional and Complementary Medicine. 2018. 8 (4). pp. 451-458. DOI 10.1016/j.jtcme.2017.08.006; Kuzmin O., Topol'nik V., Myronchuk V. Eduction of equilibrium state in vodkas by means of ${ }^{1} H$ NMR spectroscopy. Ukrainian journal of food science. 2014. 2 (2). pp. 220-228; Kuzmin O., Topol'nik V., Fatiukha A., Volkova G. ${ }^{l} H$ NMR analysis of the aqueousalcoholic mixtures, prepared in demineralized by reverse osmosis water. The advanced science journal. 2014. 8. pp. 235-240. DOI: 10.15550/ASJ.2014.08.235. 
- development of custard composition.

The object of study are the characteristics and quality indicators of infusions of alcohol from vegetable raw materials, sweet creams: organoleptic characteristics (color, aroma, taste); physicochemical parameters ( $\mathrm{pH}$ level, redox potential, reduction/oxidation energy).

The subject of the study is a aqueous-alcoholic solution (control); infusions of alcohol from vegetable raw materials: peel of grapefruit, orange, lemon, pomelo, mandarin, kumquat; custard.

For the preparation of infusions used aqueous-alcoholic solution with a volume fraction of ethyl alcohol - 40\%; vegetable raw materials - in accordance with the current regulations, which is allowed by the central executive body in the field of health of Ukraine.

Materials and methods. In the first stage, the vegetable raw material was ground to a size of $3 \times 3 \mathrm{~mm}$, a portion of $4 \mathrm{~g}$ was placed in glass vials, $100 \mathrm{ml}$ of alcohol-containing solvent with a volume fraction of alcohol of $40 \%$ was poured. The vials were closed with lids and placed in a dry air thermostat for 48 hours at a temperature of $40{ }^{\circ} \mathrm{C}$. The resulting infusions were cooled to $20^{\circ} \mathrm{C}$ and filtered.

The $\mathrm{pH}$ level was measured on a $\mathrm{pH}$ meter $\langle\mathrm{pH}-150 \mathrm{MI} »$ with a combined glass electrode ESC-10603. The redox potential was measured in the potential measurement mode with a combined redoxmetric platinum electrode ERP-105.

\section{Characterization of the technological process of extracting}

Aqueous-alcohol infusion is a semi-finished product of liqueur-vodka production, which is prepared by infusion of vegetable raw materials (aromatic and non-aromatic) in aqueous-alcoholic solution with a strength of $40 \%$ to $90 \%$, according to the technological instruction and the technological regulations with the observance of state sanitary rules and regulations.

Aqueous-alcohol infusions are obtained by extraction with aqueousalcohol liquid of dried vegetable raw materials. In the process of extraction, the phenomenon of diffusion based on equalization of concentrations between the solvent and the solution of substances contained in the plant cell is used. This equalization of concentrations is expressed in the gradual mutual penetration of two substances bordering each other, and is caused by the chaotic motion of molecules, their kinetic energy.

The degree of extraction of soluble substances depends on the degree of grinding of raw materials; the ratio of raw materials and aqueousalcohol mixture; the concentration of alcohol in the aqueous-alcohol 
mixture; duration of infusion; numbers of raw material bay; mixing frequencies; temperature.

The simplest method of extraction is double infusion (maceration) at normal temperature, which consists of the following operations: raw material acceptance and weighing; sorting of raw materials and disposal of waste; waste weighing; grinding of raw materials; preparation of aqueous-alcohol mixture of the required strength; loading of raw materials into a full container; pouring raw materials with a aqueousalcohol mixture; infusion of raw materials with a aqueous-alcohol mixture with daily stirring for 5-14 days, depending on the type of raw materials; draining and pumping the infusion of the first drain into storage compartments and measuring the volume of infusion received; the second raw material feed with an aqueous-alcoholic mixture; reinfusion of raw materials with aqueous-alcohol mixture with daily stirring for 5-10 days; draining, pumping and measuring the volume of the infusion of the first and second drains; mixing of infusions of the first and second drains; unloading of spent raw materials from an insulated container; evaporation of the alcohol remaining in the raw material.

Due to the infusion of raw materials in the aqueous-alcoholic environment is extracted tannins substances, caffeine, vitamins, organic acids, essential oils, minerals, which lead to an increase in antioxidant properties and increase the time of sale of finished products.

One of the limiting stages of alcohol production is the process of preparation of appropriate high-quality blends. The existing technology of blends involves homogenization and distribution of flavored components in a bathed container by mechanical mixing with stirrers, or by conducting a closed circulation cycle according to the scheme: capacity - pump - capacity. A significant disadvantage of these homogenization schemes is the duration of the process.

These methods of homogenization allow to obtain blends, the quality of which is provided by the regulatory documentation with tolerances. However, even the permissible deviation from the norm of such components as alcohol and sugar, leads to a decrease in the taste of the drink and, as a consequence, consumer properties.

One of the important areas of development of the food industry is to improve the taste, aroma of food, preservation (or supplementation) of the nutritional value of the final product. In most countries, functional, energy products containing biologically active substances of targeted action from natural raw materials are becoming widespread. The creation of a number of new products with the use of food additives (including 
extracts) for people of all ages and body conditions is aimed at maintaining and improving their health.

A large group of flavoring substances are plant products that also have biological value: vitamins, trace elements, carotene, natural acids and others. Many substances have medicinal properties, which provides their therapeutic and prophylactic effect in a variety of foods. Currently, more than 200 species of medicinal plants are known, of which about $65 \%$ are wild plants that can be wisely used in the food industry.

\section{Characteristics of custard technology}

To prepare the custard, granulated sugar was rubbed with an egg, then flour was added, the resulting mass was diluted with milk and boiled to a density of $1.22-1.25 \mathrm{~kg} / \mathrm{dm}^{3}$ with constant stirring to avoid the formation of lumps in the cream. The resulting cream was cooled to a temperature of $20{ }^{\circ} \mathrm{C}$ and mixed with an infusion of alcohol from vegetable raw materials. The result was a viscous custard with a moisture content of 45$50 \%$ with tons of vegetable raw materials extracted into an alcoholic liquid. According to the results of the research, a tasting evaluation was performed and the more optimal composition of the custard recipe with the addition of alcoholic infusions from vegetable raw materials was determined.

The redox potential is an indicator of the biological activity of solutions ${ }^{9}$, which characterizes the deviation from the ionic balance of free electrons in a liquid medium ${ }^{10}$.

The $\mathrm{pH}$ of aqueous solutions is in the range from 0 to 14 . If the water content of $\mathrm{H}_{3} \mathrm{O}^{+}$is reduced compared to $\mathrm{OH}^{-}$ions, then the water will have an alkaline reaction $(\mathrm{pH}>7)$, with an increased content of

9 Леонов Б.И., Прилуцкий В.И., Бахир В.М. Физико-химические аспекты биологического действия электрохимически активированной воды : монография. Москва : ВНИИИМТ. 1999. 244 с.

10 Бахир В.М. Медико-технические системь и технологии для синтеза электрохимически активированных растворов. М. ВНИИИМТ. 1998. 66 с.; Kuzmin O., Topol'nik V. Eduction of unsteady equilibrium in vodkas by means of ${ }^{1} H$ NMR spectroscopy. The advanced science journal. 2014. 10. pp. 43-46. DOI: 10.15550/ASJ.2014.10.043; Kuzmin O., Topol'nik V., Fatiukha A., Volkova G. ${ }^{1} H$ NMR analysis of the aqueous-alcoholic mixtures, prepared with softened water using Na-cationization. The advanced science journal. 2014. 7. pp. 9-14. DOI: 10.15550/ASJ.2014.07.009; Kuzmin O., Sujkov S., Topol'nik V. The change of the hydroxyl protons in aqueous alcoholic mixtures under the process of making vodkas. The advanced science journal. 2013. December. pp. 15-27. 
$\mathrm{H}_{3} \mathrm{O}^{+}$ions - acidic $(\mathrm{pH}<7)$, with equal concentrations of $\mathrm{H}_{3} \mathrm{O}^{+}$ions and $\mathrm{OH}^{-}$- neutral $(\mathrm{pH}=7)$.

The change in the concentration of free electrons leads to a change in its electronic charge and, accordingly, in the redox potential. If the redox potential is positive, it indicates the oxidative capacity of the solution, and negative - the reducing ${ }^{11}$. Thus, the magnitude of the redox potential allows us to assess the activity of ions in redox reactions ${ }^{12}$.

For aqueous-alcoholic mixtures, the relationship between $\mathrm{pH}(\mathrm{pH})$ and redox potential (Eh) was experimentally determined. It is proved that the change in the $\mathrm{pH}$ level of aqueous-alcohol mixtures by 1 unit. $\mathrm{pH}$ leads to a change in the redox potential by $42 \mathrm{mV}$.

The expected theoretical values of the redox potential of aqueous-alcohol mixtures $\left(E h_{\min }\right)$ were correlated with the actually measured values of the redox potential of infusions of alcohol from vegetable raw materials by platinum electrode $\left(\mathrm{Eh}_{\mathrm{act}}\right)$, which characterizes the difference reductive/oxidative values of infusions of alcohol from vegetable $\left(\mathrm{RE}_{\mathrm{inf}}\right)$ :

$$
\begin{gathered}
\mathrm{Eh}_{\text {min }}=502-42 \cdot \mathrm{pH}, \mathrm{mV}, \\
\mathrm{RE}_{\mathrm{inf}}=\mathrm{Eh}_{\text {min }}-\mathrm{Eh}_{\mathrm{act}}, \mathrm{mV},
\end{gathered}
$$

where $E h_{\text {min }}$ - minimum theoretically expected value of the redox potential;

$\mathrm{Eh}_{\mathrm{act}}$ - actual measured redox potential of the solution;

$\mathrm{RE}_{\text {inf }}$ - the value of the reducing/oxidizing ability of the infusion of alcohol from vegetable raw materials.

11 Бахир В.М. Медико-технические системы и технологии для синтеза электрохимически активированных растворов. Москва : ВНИИИМТ. 1998. 66 с.

${ }^{12}$ Kawa-Rygielska J., Adamenko K., Kucharska A.Z., Szatkowska K. Fruit and herbal meads - Chemical composition and antioxidant properties. Food Chemistry. 2019. 283. pp. 19-27. DOI 10.1016/j.foodchem.2019.01.040; Kuzmin O., Topol'nik V. Eduction of transitional equilibrium in vodkas by means of ${ }^{1} H$ NMR spectroscopy. The advanced science journal. 2014. 12. pp. 61-64. DOI: 10.15550/ASJ.2014.12.061; Fotakis C., Tsigrimani D., Tsiaka T., Lantzouraki D.Z., Zoumpoulakis P. Metabolic and antioxidant profiles of herbal infusions and decoctions. Food Chemistry. 2016. 211. pp. 963-971. DOI 10.1016/j.foodchem.2016.05.124; Pyrzynska K., Sentkowska A. Herbal Beverages as a Source of Antioxidant Phenolics. Natural Beverages. 2019. 5. pp. 125-142. DOI 10.1016/B978-0-12-816689-5.00005-5; Herrera T., Aguilera Y., Rebollo-Hernanz M., Bravo E., Martín-Cabrejas M.A. Teas and herbal infusions as sources of melatonin and other bioactive non-nutrient components. LWT. 2018. 89. pp. 65-73. DOI 10.1016/j.lwt.2017.10.031. 
The energy of reduction/oxidation of vegetable raw materials $\left(\mathrm{RE}_{\mathrm{veg}}\right)$ was determined by the difference between the reducing/oxidizing ability of infusions of alcohol from vegetable raw materials $\left(\mathrm{RE}_{\mathrm{inf}}\right)$ and solvent $\left(\mathrm{RE}_{\mathrm{sol}}\right)$ :

$$
\mathrm{RE}_{\mathrm{veg}}=\mathrm{RE}_{\mathrm{inf}}-\mathrm{RE}_{\mathrm{sol}}, \mathrm{mV} \text {, }
$$

At redoxmetry (measurement on a platinum electrode relative to a chlorine silver reference electrode) the redox potential of the internal environment of a healthy human body is less than zero $(-100 \ldots-200 \mathrm{mV})$. In this case, the redox potential of drinking water from the urban water supply network, depending on the location of the water intake, the time of year, the water treatment system (except for electrochemical activation) is always greater than zero $(+100 \ldots+400 \mathrm{mV})^{13}$.

These differences of redox potential of the internal environment of the human body and drinking water mean that the activity of electrons in the internal environment of the body is much higher than the activity of electrons in drinking water. In the body there is a necessary change in the redox potential of drinking water due to the consumption of electrical energy of cell membranes, i.e. energy of the highest level, energy, which is actually the end product of the biochemical chain of nutrient transformation. The amount of energy consumed by the body to achieve the biological compatibility of water is proportional to its amount and the difference of the redox potential of water and the internal environment of the body ${ }^{14}$.

In addition to drinking water, a person consumes water and aqueousalcohol mixtures, food, the redox potential of which is positive. When such products get into the body tissues, electrons are removed from cells and tissues, which are $80-90 \%$ composed of water. As a result, the biological structures of the organism (cell membranes, cell organoids, nucleic acids, etc.) are subjected to oxidative destruction, the organism wears out, ages, and vital organs lose their function.

When aqueous solutions (food) with a negative redox potential close to the values of the redox potential of the internal environment of the human body enter the body, the electrical energy of the cell membranes is not spent on the correction of the activity of the electrons of aqueous

${ }^{13}$ Бахир В.М. Современные технические электрохимические системы для обеззараживания, очистки и активирования воды. М.: ВНИИИМТ, 1999. 84 с.; Dube P., Meyer S., Marnewick J.L. Antimicrobial and antioxidant activities of different solvent extracts from fermented and green honeybush (Cyclopia intermedia) plant material. South African Journal of Botany. 2017. 110. pp. 184-193. DOI 10.1016/j.sajb.2016.10.010.

14 Бахир В.М. Современные технические электрохимические системы для обеззараживания, очистки и активирования воды. Москва : ВНИИИМТ, 1999. 84 с. 
solutions (food), so the products are immediately assimilated because they have biological compatibility under this parameter.

If aqueous solutions (food) have a redox potential more negative than the redox potential of the internal environment of the body, then they feed it with this energy, which is used by cells as an energy reserve of antioxidant protection of the body against the adverse effects of the external environment ${ }^{15}$.

We can conclude that in order for the human body to optimally use in the metabolic processes aqueous solutions (food), the values of redox potential must correspond to the values of redox potential of the internal environment of the organism, or have more negative values ${ }^{16}$.

\section{Research of alcohol infusions from vegetable raw materials}

For the study, 6 samples of vegetable raw materials - peel: lemon, grapefruit, tangerine, orange, pomelo, kumquat and 1 sample - vodka (control), which were used in the extraction by infusion. The obtained infusions of alcoholic vegetable raw materials were evaluated by organoleptic and physicochemical parameters (Table 1-2), which are presented in Figures 1-7.

Sensory evaluation of control: color - transparent; aroma - alcohol; taste - burning with a synthetic aftertaste. The control sample at $\mathrm{t}=18{ }^{\circ} \mathrm{C}$ has a $\mathrm{pH}$ value of $8.27, \mathrm{Eh}_{\min }=154.66 \mathrm{mV}, \mathrm{Eh}_{\text {act }}=187 \mathrm{mV}$, $\mathrm{RE}_{\mathrm{inf}}=-32.34 \mathrm{mV}, \mathrm{RE}_{\mathrm{veg}}=-116.84 \mathrm{mV}$.

${ }^{15}$ Бахир В.М. Электрохимическая активация. М.: ВНИИИМТ. 1992. 2 ч. 657 с.; Прилуцкий В.И., Бахир В.М. Электрохимически активированная вода: аномальные свойства, механизм биологического действия. Москва : ВНИИИМТ. 1997. 228 с.; Леонов Б.И., Прилуцкий В.И., Бахир В.М. Физикохимические аспекты биологического действия электрохимически активированной воды : монография. Москва : ВНИИИМТ. 1999. 244 с.; Бахир В.М. Медико-технические системы и технологии для синтеза электрохимически активированных растворов. М. ВНИИИМТ. 1998. $66 \mathrm{c}$.

${ }^{16}$ Прилуцкий В.И., Бахир В.М. Электрохимически активированная вода: аномальные свойства, механизм биологического действия. Москва : ВНИИИМТ. 1997. 228 с.; Леонов Б.И., Прилуцкий В.И., Бахир В.М. Физикохимические аспекты биологического действия электрохимически активированной воды : монография. М.: ВНИИИМТ. 1999. 244 с.; Бахир В.М. Медико-технические системы и технологии для синтеза электрохимически активированных растворов. Москва : ВНИИИМТ. 1998. 66 с.; Бахир В.М. Современные технические электрохимические системы для обеззараживания, очистки и активирования воды. Москва : ВНИИИМТ, 1999. 84 с. 
Table 1

Organoleptic parameters of the studied samples

\begin{tabular}{|c|c|c|c|c|c|}
\hline № & $\begin{array}{c}\text { Plant raw } \\
\text { materials }\end{array}$ & Color & Aroma & Test & $\begin{array}{c}\text { S.e., } \\
\text { points }\end{array}$ \\
\hline 1 & Vodka (control) & transparent & spirituous & $\begin{array}{c}\text { burning, } \\
\text { synthetic } \\
\text { aftertaste }\end{array}$ & 9.61 \\
\hline 2 & $\begin{array}{c}\text { Infusion of } \\
\text { alcohol peel of } \\
\text { grapefruit }\end{array}$ & $\begin{array}{c}\text { transparent, } \\
\text { light straw }\end{array}$ & $\begin{array}{c}\text { alcoholic, } \\
\text { faint odor of } \\
\text { citrus }\end{array}$ & soft, tart & 9.62 \\
\hline 4 & $\begin{array}{c}\text { Infusion of } \\
\text { alcohol peel of } \\
\text { orange }\end{array}$ & $\begin{array}{c}\text { transparent, } \\
\text { light yellow } \\
\text { alcohol peel of } \\
\text { lemon }\end{array}$ & $\begin{array}{c}\text { faint smell of } \\
\text { alcohol, fresh }\end{array}$ & soft, sweet & 9.65 \\
\hline 5 & $\begin{array}{c}\text { Infusion of } \\
\text { alcohol peel of } \\
\text { pomelo }\end{array}$ & $\begin{array}{c}\text { transparent, } \\
\text { light straw }\end{array}$ & $\begin{array}{c}\text { faint smell of } \\
\text { alcohol, } \\
\text { lemon }\end{array}$ & $\begin{array}{c}\text { soft, sweet, } \\
\text { lemon flavor }\end{array}$ & 9.63 \\
\hline 6 & $\begin{array}{c}\text { Infusion of } \\
\text { alcohol peel of } \\
\text { mandarin }\end{array}$ & $\begin{array}{c}\text { transparent, } \\
\text { light yellow }\end{array}$ & $\begin{array}{c}\text { faint smell of } \\
\text { alcohol, } \\
\text { tangerine }\end{array}$ & soft, sweet & 9.64 \\
\hline 7 & $\begin{array}{c}\text { Infusion of } \\
\text { alcohol peel of } \\
\text { kumquat }\end{array}$ & $\begin{array}{c}\text { transparent, } \\
\text { light yellow }\end{array}$ & $\begin{array}{c}\text { faint smell of } \\
\text { alcohol, fresh }\end{array}$ & soft, sweet & 9.66 \\
\hline
\end{tabular}

Table 2

Indicators of redox capacity of infusions

of alcohol from vegetable raw materials

\begin{tabular}{|c|c|c|c|c|c|c|}
\hline № & Raw materials & $\mathbf{p H}$ & $\begin{array}{c}\mathbf{E h}_{\mathbf{m i n}}, \\
\mathbf{m V}\end{array}$ & $\begin{array}{c}\mathbf{E h}_{\text {act }}, \\
\mathbf{m V}\end{array}$ & $\begin{array}{c}\mathbf{R E}_{\text {inf }} \\
\mathbf{m V}\end{array}$ & $\begin{array}{c}\mathbf{R E}_{\text {veg, }} \\
\mathbf{m V}\end{array}$ \\
\hline 1 & Vodka (control) & 8.27 & 154.66 & 187 & -32.34 & -116.84 \\
\hline 2 & $\begin{array}{c}\text { Infusion of alcohol peel } \\
\text { of grapefruit }\end{array}$ & 6.43 & 231.94 & 43 & 188.94 & 104.44 \\
\hline 3 & $\begin{array}{c}\text { Infusion of alcohol peel } \\
\text { of orange }\end{array}$ & 6.21 & 241.18 & 67 & 174.18 & 89.68 \\
\hline 4 & $\begin{array}{c}\text { Infusion of alcohol peel } \\
\text { of lemon }\end{array}$ & 7.01 & 207.58 & 194 & 13.58 & -70.92 \\
\hline 5 & $\begin{array}{c}\text { Infusion of alcohol peel } \\
\text { of pomelo }\end{array}$ & 6.71 & 220.18 & 15 & 205.18 & 120.68 \\
\hline 6 & $\begin{array}{c}\text { Infusion of alcohol peel } \\
\text { of mandarin }\end{array}$ & 6.64 & 223.12 & 139 & 84.12 & -0.38 \\
\hline 7 & $\begin{array}{c}\text { Infusion of alcohol peel } \\
\text { of kumquat }\end{array}$ & 5.53 & 269.74 & 171 & 98.74 & 14.24 \\
\hline & min & $\mathbf{5 . 5 3}$ & $\mathbf{2 0 7 . 5 8}$ & $\mathbf{1 5}$ & $\mathbf{1 3 . 5 8}$ & $\mathbf{- 7 0 . 9 2}$ \\
\hline & max & $\mathbf{7 . 0 1}$ & $\mathbf{2 6 9 . 7 4}$ & $\mathbf{1 9 4}$ & $\mathbf{2 0 5 . 1 8}$ & $\mathbf{1 2 0 . 6 8}$ \\
\hline
\end{tabular}




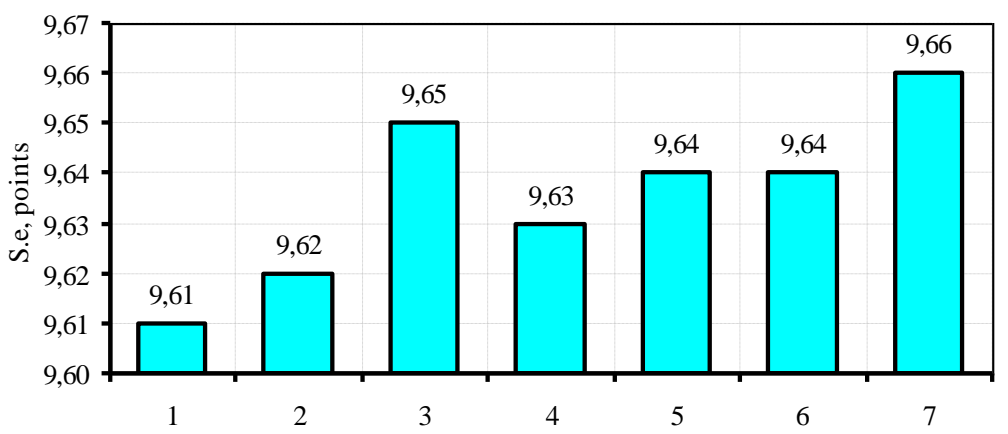

Fig. 1. Sensory evaluation of aqueous-alcohol infusions of vegetable raw materials

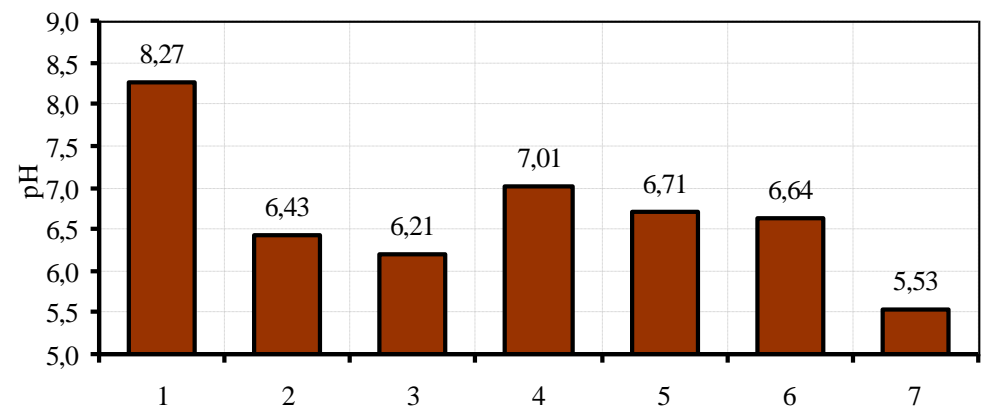

Fig. 2. pH level of aqueous-alcohol infusions of vegetable raw materials

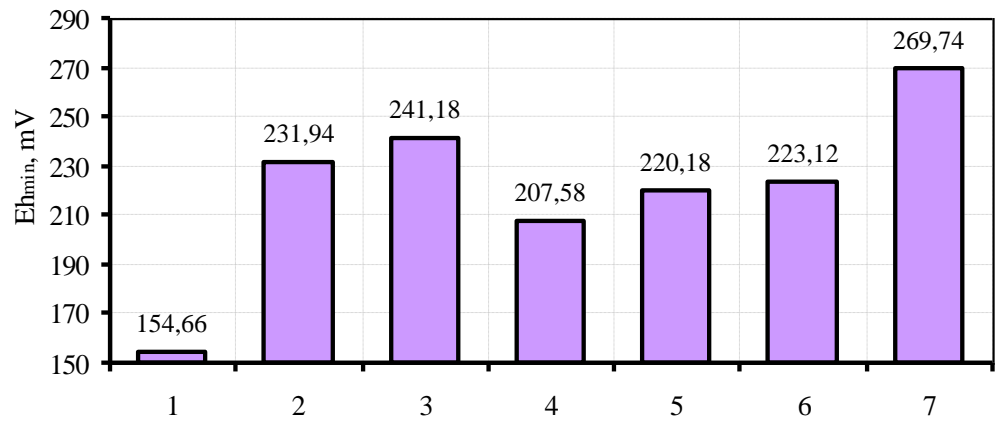

Fig. 3. $\mathrm{Eh}_{\min }$ of aqueous-alcohol infusions of vegetable raw materials 


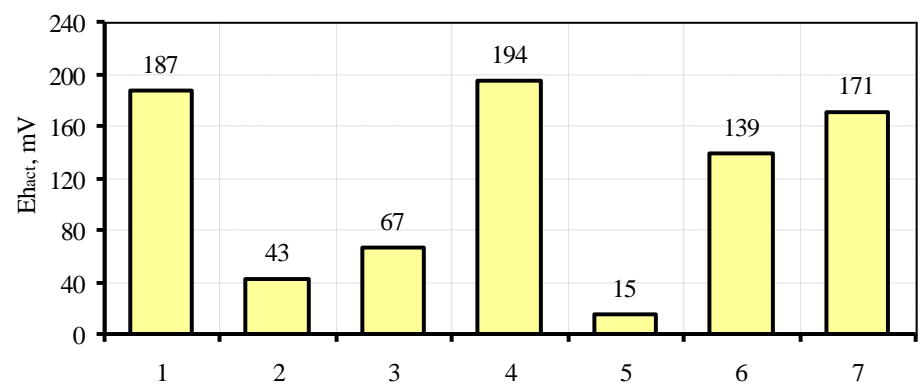

Fig. 4. $\mathrm{Eh}_{\text {act }}$ of aqueous-alcohol infusions of vegetable raw materials

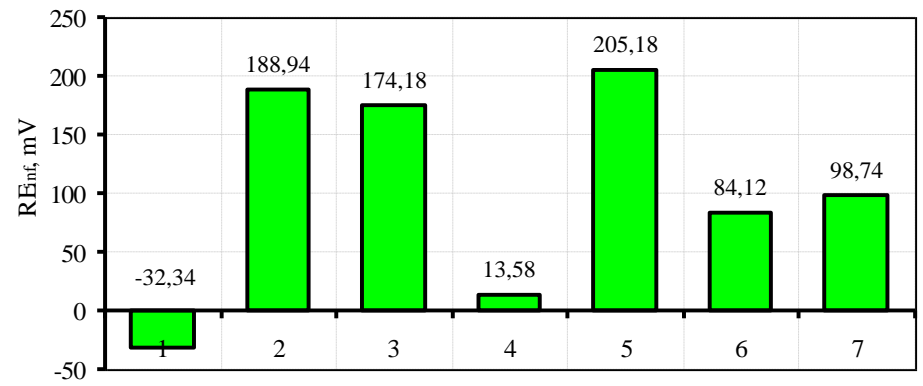

Fig. 5. $\mathrm{RE}_{\mathrm{inf}}$ of aqueous-alcohol infusions of vegetable raw materials

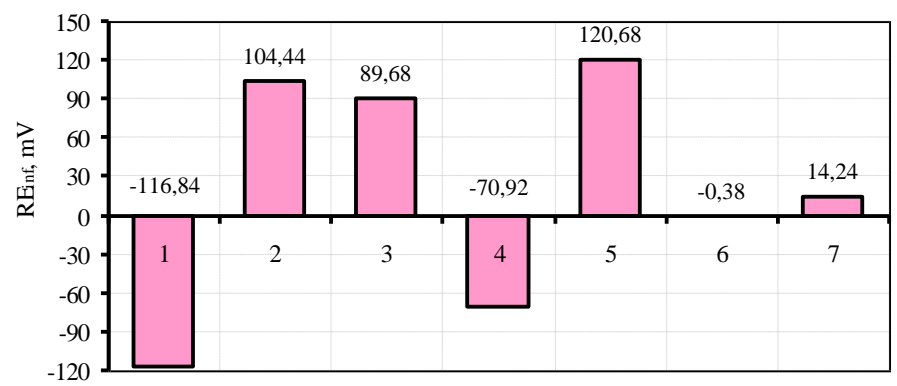

Fig. 6. $\mathrm{RE}_{\mathrm{veg}}$ of vegetable raw materials 


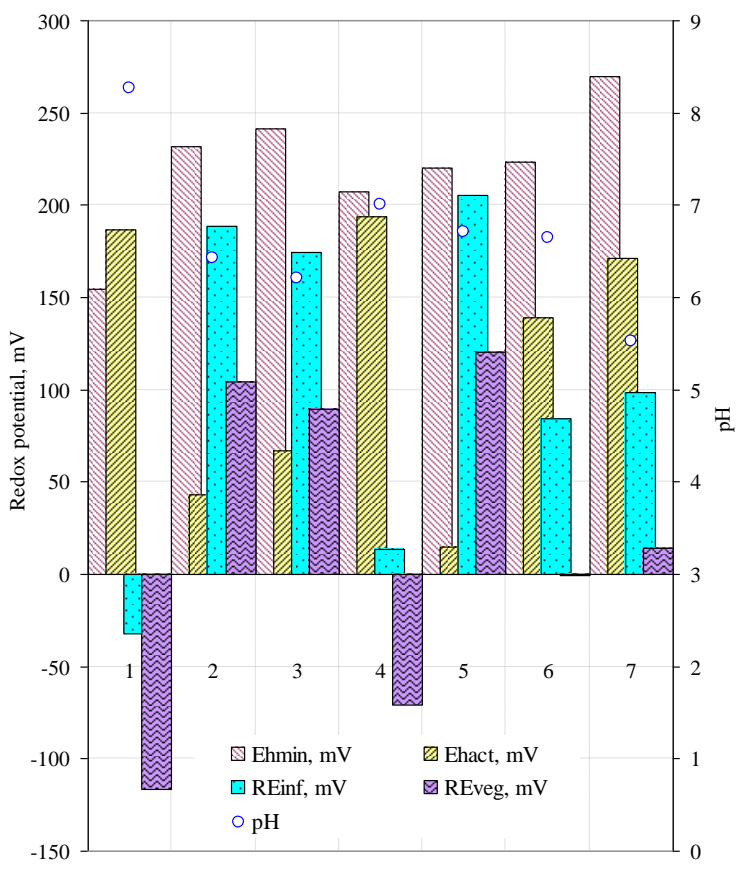

Fig. 7. Graphic dependence of physicochemical parameters of water-alcohol infusions from plant raw materials

The $\mathrm{pH}$ level for infusions of alcohol from vegetable raw materials ranges from 5.53 (infusion of alcohol peel of kumquat) to 7.01 (infusion of alcohol peel of lemon).

The minimum theoretically expected value of the redox potential of $\mathrm{Eh}_{\text {min }}$ for infusions of alcohol from vegetable raw materials ranges from $207.58 \mathrm{mV}$ (infusion of alcohol peel of lemon) to $269.74 \mathrm{mV}$ (infusion of alcohol peel of kumquat), and the actual measured redox potential of $\mathrm{Eh}_{\text {min }}$ from $15 \mathrm{mV}$ (infusion of alcohol peel of pomelo) to $194 \mathrm{mV}$ (infusion of alcohol peel of lemon). In this case, the minimum value of the regenerative capacity of infusions of alcohol from vegetable raw materials $\left(\mathrm{RE}_{\text {inf }}\right)$ is $13.58 \mathrm{mV}$ and is characteristic of the infusion of alcohol peel of lemon, and the highest value of $205.18 \mathrm{mV}$ is the infusion of alcohol peel of pomelo. The minimum value of energy of reduction/oxidation of vegetable raw materials $\left(\mathrm{RE}_{\mathrm{veg}}\right)$ is $-70.92 \mathrm{mV}$ and is typical for the infusion of alcohol peel 
of lemon, and the highest value of $120.68 \mathrm{mV}$ is the infusion of alcohol peel of pomelo.

It was found that alcohol infusions, depending on the activity of plant raw materials have a regenerative capacity of $\mathrm{RE}_{\mathrm{veg}}-$ more than $0 \mathrm{mV}-$ $67 \%$ of samples (infusions of alcohol peel of pomelo, grapefruit, orange, kumquat) and oxidizing capacity - less than $0 \mathrm{mV}-33 \%$ of samples (infusions of alcohol peel of mandarin and lemon).

Infusions of alcohol from plant raw materials contain the most important micronutrients, which provides strong antioxidant properties. Polyphenolic substances strengthen blood vessels, so a cream with the addition of alcohol infusions can be recommended for diets of people with heart failure. Antioxidant properties of alcohol infusions from plant raw materials are also increased due to polyphenolic compounds ${ }^{17}$.

Therefore, the infusion of alcohol peel pomelo showed the greatest value of antioxidant capacity. He received relatively high marks for organoleptic characteristics and can be recommended for the technology of creams according to the recipe № 78, with a mass ratio of components.

The disadvantages of this composition of ingredients (recipe № 78) are: the specified value of the redox potential, which should change the speed and direction of the redox potential in the body; predictable (standard) organoleptic characteristics ${ }^{18}$.

The main task was to create a cream with the addition of vegetable aqueous-alcohol infusion, which will increase the redox properties of the product, which will increase the body's immunity, improve metabolism, have a positive effect on the cardiovascular system, and provide confectionery with improved consumer properties and will increase the warranty period.

17 Kuzmin O.V., Rudyi V.V. Prospects for the use of alcohol infusions in alcoholic beverage technologies for restaurants. Modern engineering research: topical problems, challenges and modernity: collective monograph. Riga. 2020. pp. 211-230. DOI 10.30525/978-9934-588-47-1.9; Kuzmin O.V., Mishurovskyi A.S. Improvement of alcoholic beverages technology for restaurant business. Scientific and technical progress in European countries and the contribution of higher education institutions : collective monograph. Riga. 2020. pp. 90-106. DOI 10.30525/978-9934-588-65-5.6; Kuzmin O.V., Isaienko V.M. Development of effective technologies for waste processing of the food industry. Scientific developments of Ukraine and EU in the area of natural sciences : collective monograph. Riga. 2020. P.2. pp. 430-448. DOI 10.30525/978-9934-588-73-0/2.3.

18 Koretska I., Kuzmin O., Zinchenko T. Sample rating in water-alcohol technology by profile non-linear quality criteria. Restaurant and hotel consulting. Innovations. 2020. 3 (1). pp. 12-24. DOI 10.31866/2616-7468.3.1.2020.205561. 


\section{Research of custard with the addition of infusions of alcohol from vegetable raw materials}

The Napoleon cake recipe was used as a prototype. Custard (Table 3) was mixed with alcohol infusions $-13 \%$ by weight of cream, baked cakes and lubricated with cream.

Table 3

Prescription composition of custard

\begin{tabular}{|c|c|}
\hline Raw & Content, wt.\% \\
\hline Granulated sugar & 10 \\
\hline Wheat flour & 22 \\
\hline Pasteurized milk & 40 \\
\hline Eggs & 15 \\
\hline Infusion of alcohol from vegetable raw materials & 13 \\
\hline
\end{tabular}

The obtained custard with the addition of infusions of alcohol from vegetable raw materials was evaluated by organoleptic parameters (table 4).

After that, prepared custard with a different ratio of components that differ from the classic recipe in that the cream was added to the infusion of alcohol from the peel of pomelo. For this purpose, samples of custard with different mass ratio of alcohol pomelo infusion were prepared, its consistency and appearance of the confectionery product were observed (table 5).

Table 4

\section{Organoleptic characteristics of custards for the addition of infusions} of alcohol from vegetable raw materials

\begin{tabular}{|c|c|c|c|c|c|}
\hline № & Plant raw materials & Color & Aroma & Test & $\begin{array}{c}\text { S.e., } \\
\text { points }\end{array}$ \\
\hline 1 & Vodka (control) & white & $\begin{array}{c}\text { creamy, } \\
\text { alcoholic }\end{array}$ & $\begin{array}{c}\text { milky, } \\
\text { burning }\end{array}$ & 7.6 \\
\hline 2 & $\begin{array}{c}\text { Infusion of alcohol peel } \\
\text { of grapefruit }\end{array}$ & $\begin{array}{c}\text { pale } \\
\text { yellow }\end{array}$ & creamy & $\begin{array}{c}\text { milky, } \\
\text { bitter }\end{array}$ & 8.2 \\
\hline 3 & $\begin{array}{c}\text { Infusion of alcohol peel } \\
\text { of orange }\end{array}$ & $\begin{array}{c}\text { pale } \\
\text { yellow }\end{array}$ & $\begin{array}{c}\text { creamy, } \\
\text { weak orange }\end{array}$ & $\begin{array}{c}\text { milky, } \\
\text { orange }\end{array}$ & 9.3 \\
\hline 4 & $\begin{array}{c}\text { Infusion of alcohol peel } \\
\text { of lemon }\end{array}$ & $\begin{array}{c}\text { pale } \\
\text { yellow }\end{array}$ & $\begin{array}{c}\text { creamy, } \\
\text { weak lemon }\end{array}$ & $\begin{array}{c}\text { milky, } \\
\text { lemon }\end{array}$ & 9.1 \\
\hline 5 & $\begin{array}{c}\text { Infusion of alcohol peel } \\
\text { of pomelo }\end{array}$ & $\begin{array}{c}\text { pale } \\
\text { yellow }\end{array}$ & creamy & milky & 8.0 \\
\hline 6 & $\begin{array}{c}\text { Infusion of alcohol peel } \\
\text { of mandarin }\end{array}$ & $\begin{array}{c}\text { pale } \\
\text { yellow }\end{array}$ & $\begin{array}{c}\text { creamy, } \\
\text { mandarin }\end{array}$ & $\begin{array}{c}\text { milky, } \\
\text { tangerine }\end{array}$ & 9.2 \\
\hline 7 & $\begin{array}{c}\text { Infusion of alcohol peel } \\
\text { of kumquat }\end{array}$ & $\begin{array}{c}\text { pale } \\
\text { yellow }\end{array}$ & $\begin{array}{c}\text { creamy, } \\
\text { citrus }\end{array}$ & $\begin{array}{c}\text { milky, } \\
\text { citrus }\end{array}$ & 9.4 \\
\hline
\end{tabular}


The mass ratio of the infusion of alcohol peel of lemon

to the total weight of the cream

\begin{tabular}{|c|c|c|c|}
\hline № & Name & Mass ratio of infusion, g/100g & Content, wt.\% \\
\hline 1 & Sample №1 & 10 & 10 \\
\hline 2 & Sample № 2 & 20 & 20 \\
\hline 3 & Sample № 3 & 30 & 30 \\
\hline 4 & Sample № 4 & 40 & 40 \\
\hline
\end{tabular}

After the tasting evaluation of confectionery, it was concluded that for their lubrication it is advisable to use custard with infusion of alcohol from the peel of pomelo with a mass fraction of $10 \%$ and $20 \%$ relative to the cream. The taste and appearance of the cream - pleasant to eat, thick without lumps, without excess odor and taste. With a mass fraction of infusion of alcohol from vegetable raw materials 30-40\% revealed shortcomings: cream - in a very liquid state and gelatinous form; cakes softened after saturation. It can be concluded that the confectionery product cannot be sold to the consumer, as it has low organoleptic characteristics.

\section{CONCLUSIONS}

The main technological properties of alcohol infusions from vegetable raw materials for the technology of creams are investigated, the influence of infusion dosages on the properties of model systems is studied. Indicators of redox capacity of alcohol infusions from vegetable raw materials are determined. The optimal dosage of alcohol infusion from vegetable raw materials for custard in the recipe of the cake is determined. The combination of all ingredients of alcoholic infusions from vegetable raw materials for lubrication of confectionery allows to obtain a universal finishing semi-finished product with a special recipe, high nutritional value, taste and versatility, which can be used for cream production.

\section{SUMMARY}

The prospects of using alcohol infusions from vegetable raw materials for the production of custard are substantiated. The minimum value of energy of reduction / oxidation of vegetable raw materials $\left(\mathrm{RE}_{\mathrm{veg}}\right)$ is $-70.92 \mathrm{mV}$ and is characteristic of the infusion of alcoholic zest of lemon, and the highest value of $120.68 \mathrm{mV}$ is the infusion of alcoholic peel of pomelo. Depending on the activity of plant raw materials, $67 \%$ of samples (alcohol infusions from pomelo peel, grapefruit, orange, kumquat) have a reducing ability. The most 
promising sources of natural antioxidants for the technology of creams are identified. The composition of custard for lubrication of confectionery products is proposed due to the addition to the recipe of vegetable water-alcohol infusion of pomelo (10-20\%), which allows to increase the redox properties of the finished product, to improve consumer properties.

\section{REFERENCES}

1. Andreou V., Strati I.F., Fotakis C., Liouni M., Sinanoglou V.J. Herbal distillates: A new era of grape marc distillates with enriched antioxidant profile. Food Chemistry. 2018. 253, pp. 171-178. DOI 10.1016/j.foodchem.2018.01.162.

2. Dietrich I., Kuzmin O., Mikhailenko V. Comprehensive evaluation of the hot sweet soufflé dessert quality. Ukrainian Journal of Food Science. 2017. 5 (1). pp. 92-102. DOI 10.24263/2310-1008-2017-5-1-12.

3. Kuzmin O., Kovalchuk Y., Velychko V., Romanchenko N. Improvement technologies of aqueous-alcoholic infusions for the production of syrups. Ukrainian Journal of Food Science. 2016.4 (2). pp. 258-275. DOI 10.24263/2310-1008-2016-4-2-8.

4. Chandrasekara A., Shahidi F. Herbal beverages: Bioactive compounds and their role in disease risk reduction - A review. Journal of Traditional and Complementary Medicine. 2018. 8 (4). pp. 451-458. DOI 10.1016/j.jtcme.2017.08.006.

5. Kuzmin O., Levkun K., Riznyk A. Qualimetric assessment of diets. Ukrainian Food Journal. 2017. 6, 1. pp. 46-60. DOI: 10.24263/2304974X-2017-6-1-7.

6. Бахир В.М. Электрохимическая активация. Москва : ВНИИИМТ. 1992.2 ч. 657 с.

7. Прилуцкий В.И., Бахир В.М. Электрохимически активированная вода: аномальные свойства, механизм биологического действия. Москва : ВНИИИМТ. 1997. 228 с.

8. Леонов Б.И., Прилуцкий В.И., Бахир В.М. Физико-химические аспекты биологического действия электрохимически активированной воды : монография. Москва : ВНИИИМТ, 1999. 244 с.

9. Бахир В.М. Медико-технические системы и технологии для синтеза электрохимически активированных растворов. Москва : ВНИИИМТ, 1998. 66 с.

10. Бахир В.М. Современные технические электрохимические системы для обеззараживания, очистки и активирования воды. Москва : ВНИИИМТ, 1999. 84 с. 
11. Kawa-Rygielska J., Adamenko K., Kucharska A.Z., Szatkowska K. Fruit and herbal meads - Chemical composition and antioxidant properties. Food Chemistry. 2019. 283. pp. 19-27. DOI 10.1016/j.foodchem.2019.01.040.

12. Kuzmin O., Suikov S., Niemirich O., Ditrich I., Sylka I. Effects of the water desalting by reverse osmosis on the process of formation of water-alcohol mixtures. ${ }^{1} H$ NMR spectroscopy studies. Ukrainian Food Journal. 2017. 6 (2). pp. 239-257. DOI: 10.24263/2304-974X-2017-6-2-6.

13. Kuzmin O., Suikov S., Koretska I., Matiyashchuk O., Poliovyk V. Identification of equilibrium state of hydroxyl protons in vodkas by ${ }^{1} H$ NMR spectroscopy. Ukrainian Food Journal. $2017.6(2)$. pp. 314-336. DOI: 10.24263/2304-974X-2017-6-1-12.

14. Kuzmin O., Topol'nik V. Eduction of transitional equilibrium in vodkas by means of ${ }^{1} H$ NMR spectroscopy. The advanced science journal. 2014. 12. pp. 61-64. DOI: 10.15550/ASJ.2014.12.061.

15. Kuzmin O., Topol'nik V., Myronchuk V. Eduction of equilibrium state in vodkas by means of ${ }^{1} H$ NMR spectroscopy. Ukrainian journal of food science. 2014. 2 (2). pp. 220-228.

16. Kuzmin O., Topol'nik V., Fatiukha A., Volkova G. ${ }^{1} H$ NMR analysis of the aqueous-alcoholic mixtures, prepared in demineralized by reverse osmosis water. The advanced science journal. 2014. 8. pp. 235-240. DOI: 10.15550/ASJ.2014.08.235.

17. Kuzmin O., Topol'nik V. Eduction of unsteady equilibrium in vodkas by means of ${ }^{1} H$ NMR spectroscopy. The advanced science journal. 2014. 10. pp. 43-46. DOI: 10.15550/ASJ.2014.10.043

18. Kuzmin O., Topol'nik V., Fatiukha A., Volkova G. ${ }^{l} H$ NMR analysis of the aqueous-alcoholic mixtures, prepared with softened water using Na-cationization. The advanced science journal. 2014. 7. pp. 9-14. DOI: 10.15550/ASJ.2014.07.009/

19. Kuzmin O., Sujkov S., Topol'nik V. The change of the hydroxyl protons in aqueous alcoholic mixtures under the process of making vodkas. The advanced science journal. 2013. December. pp. 15-27.

20. Fotakis C., Tsigrimani D., Tsiaka T., Lantzouraki D.Z., Zoumpoulakis P. Metabolic and antioxidant profiles of herbal infusions and decoctions. Food Chemistry. 2016. 211. pp. 963-971. DOI 10.1016/j.foodchem.2016.05.124.

21. Pyrzynska K., Sentkowska A. Herbal Beverages as a Source of Antioxidant Phenolics. Natural Beverages. 2019. 5. pp. 125-142. DOI 10.1016/B978-0-12-816689-5.00005-5/

22. Herrera T., Aguilera Y., Rebollo-Hernanz M., Bravo E., MartínCabrejas M.A. Teas and herbal infusions as sources of melatonin and 
other bioactive non-nutrient components. LWT. 2018. 89. pp. 65-73. DOI 10.1016/j.lwt.2017.10.031.

23. Dube P., Meyer S., Marnewick J.L. Antimicrobial and antioxidant activities of different solvent extracts from fermented and green honeybush (Cyclopia intermedia) plant material. South African Journal of Botany. 2017. 110. pp. 184-193. DOI 10.1016/j.sajb.2016.10.010.

24. Kuzmin O.V., Rudyi V.V. Prospects for the use of alcohol infusions in alcoholic beverage technologies for restaurants. Modern engineering research: topical problems, challenges and modernity: collective monograph. Riga. 2020. pp. 211-230. DOI 10.30525/9789934-588-47-1.9.

25. Kuzmin O.V., Mishurovskyi A.S. Improvement of alcoholic beverages technology for restaurant business. Scientific and technical progress in European countries and the contribution of higher education institutions : collective monograph. Riga. 2020. pp. 90-106. DOI 10.30525/978-9934-588-65-5.6.

26. Kuzmin O.V., Isaienko V.M. Development of effective technologies for waste processing of the food industry. Scientific developments of Ukraine and EU in the area of natural sciences : collective monograph. Riga. 2020. P.2. pp. 430-448. DOI 10.30525/9789934-588-73-0/2.3.

27. Koretska I., Kuzmin O., Zinchenko T. Sample rating in wateralcohol technology by profile non-linear quality criteria. Restaurant and hotel consulting. Innovations. 2020. 3 (1). pp. 12-24. DOI 10.31866/2616-7468.3.1.2020.205561.

\section{Information about authors: Kuzmin O. V., $\mathrm{PhD}$,} Associate Professor at the Department of Technology of Restaurant and Ayurvedic Products National University of Food Technologies 68, Volodymyrska str., Kyiv, 01601, Ukraine

Rizhenko V. V.,

Master's Student

National University of Food Technologies 68, Volodymyrska str., Kyiv, 01601, Ukraine 